\title{
Evaluation of Computer Science and Software Engineering Undergraduate's Soft Skills in Egypt from Student's Perspective
}

\author{
Sarah Naiem ${ }^{1}$, Mahmoud M. Abdellatif ${ }^{1} \&$ Salama S. $E^{1}$ \\ ${ }^{1}$ Faculty of computer and information, Hellwan University, Cairo, Egypt \\ Correspondence: Sarah Naiem, Faculty of computer and information, Hellwan University, Cairo, Egypt. E-mail: \\ eng.sarahnaiem@gmail.com
}

Received: November 2, 2014

Accepted: November 18, $2014 \quad$ Online Published: January 2, 2015

doi:10.5539/cis.v8n1p36

URL: http://dx.doi.org/10.5539/cis.v8n1p36

\begin{abstract}
Soft skills for software engineers turned out to be a very important factor in the success of any project helping the team's dynamics and performance. Conversely, computer science undergraduates are possibly not aware of the importance of soft skills for their careers. Accordingly this paper's main purpose is to highlight the gaps that exist for computer science graduates in Egypt. In this paper we present a simplified systematic literature review approach for this topic. A survey is conducted in Hellwan University, Cairo, Egypt where 136 computer and software engineering graduating students participated. The survey purpose was to uncover how students evaluate the importance of softs skills, how much they attain these skills, in addition to how much they think the university is helping its development. One outcome of our analysis is that there is a lack of understanding on how to define and thus provide those soft skills for computer science graduating students in Egypt.
\end{abstract}

Keywords: soft skills, Software engineering, computer science graduates, systematic literature review, Egyptian software engineering students

\section{Introduction}

\subsection{Problem Introduction}

A software engineering or a computer science graduate in general needs to acquire some technical skills throughout their studying years in as many specialized areas as possible. These skills are divided into 5 categories including project management, analysis and design, programming, testing and documentations. Each one of these five categories includes a wide range of tasks and skills that any software engineer should be familiar with. Educators generally focus on transferring this set of technical skills and overlooking the soft skills ignoring its impact on the future of students. Resulting in the formation of the current gap between what the software engineering job markets are looking for and the level of the existing fresh graduates.

\subsection{Importance of the Problem}

This paper discusses the importance of soft skills (non-technical skills) in the computer science field and highlights the existence of a gap between the level of graduates and the markets requirements. In addition to that, it uncovers the fact that students perceiving computer science higher education in Egypt lack the basic understanding of the soft skills and its importance. The importance of soft skills for the field has been emphasized as it is one of the reasons behind the failure of software development houses projects. These projects generally fail due to lack of understanding of the importance and significance of the human factor and its effect on the project's success.

This paper includes a description of the research approach followed by a literature review regarding the importance of soft skills from different perspectives. In addition to that, the conclusion derived from several interviews conducted with some small Egyptian software development houses. Followed by the survey design and methodology, along with analysis of the data and a discussion of the results obtained.

State why the problem deserves new research. For basic research, the statement about importance might involve the need to resolve any inconsistency in results of past work and/or extend the reach of a theoretical formulation.

\subsection{Background}

The term "Behavioral Skills" or "Soft skills" is being underestimated especially when it comes to science or 
engineering field. In general, teaching and assessing soft skills have been proven to be a very stiff mission. Several researches had been conducted to highlight the fact that graduating computer science students lack the set of required soft skills and also lack the understanding of its importance for their future careers (Radermacher, A. 2013; J. Carver and N. Kraft, 2011; E. Brechner, 2003; T. Koppi et, al 2010). Alex Radermacher and Gursimran Walia 2013 in their study mentioned that it's important to create a term that describes the insufficiency of students in term of the skills they lack. The term they used is "Knowledge deficiency" which describes "Any skill, ability or knowledge concept which a recently graduate student lacks based on the expectations of industry or academia". In order to fix this dilemma students have to, first, understand what soft skills are, and also educators have to be aware of its importance. It has been noted in other studies that higher education should cultivate the student's generic skills or soft skills along with the other technical skills and required knowledge in their field. This is because soft skills will help them in a lot of the situations that will face them in the working environment (Robert Feldt, 2012).

Soft skills can generally be defined in different form and contexts. King, 2012 stated that "Soft skills are transferable behaviors that can be used within a wide range of functions, activities and contexts." King also mentioned that soft skills together with technical skills are indispensable for the working environments (King, 2012). Soft skills include a large range of skills that are related to the characteristic of the individuals including communications skills, leadership, creativity, negotiation skills, planning and management skills, presentation skills and lots of other skills that will be further introduced in this paper.

There is more than one approach to deliver these skills to students. The first approach is directly through human development courses or indirectly within the curriculum of the subjects being taught. The second approach has been proven to be better as it helps link between the technical and softs skill that students should acquire (Lutz, M. 2013; Burlea, A. S 2009; Lingard, R. W. 2010). This is achieved throughout assignments and projects that require students to work together in teams in order to deliver a small scaled complete project that is close to real life projects and tasks that they will face when they start working and being graded according to the quality of their project along with how well they worked as a team (Lingard, R. W. 2010). Nevertheless, the professors fail to deliver the point of teaching soft skills and they only grade the projects from the technical point of view, which was highlighted by asking the students to evaluate the teaching techniques they were offered (Makasiranondh, W., et.al 2011).The importance of soft skills for computer science and software engineering field generally is reflected in the huge demand by organizations (Matturro, G. 2013). Organizations claim that the acquisition of soft skills complements the technical skills and it's something that job applicants must have in order to get the offered jobs. Not only that but also to assure better influence to the objectives of these organizations (Robert Feldt 2012).

Large parties in the software development area such as the Software Engineering Institute's (SEI) Capability Maturity Model (CMM), at first used to focus only on the resources of production methods, techniques, and/or tools. Nevertheless, now The People-Capability Maturity Model (PCMM) has been introduced into the software engineering process. The PCMM focuses on the importance of soft skills by explaining how people can best change their behavior to fit the CMM approach. Together, the CMM and PCMM reflect the conventional approach of production first and people second (Bill Cuties et,al 2009; Sayer S2004). Basically PCMM is shifting the focus from the process to the people aspect in the organization. That's to say instead of measuring the results the organization measures the improvement and consider its employees as an investment instead of an expense and that can be done by considering people as assets.

The introduction of PCMM has a significant impact on the concept and purpose of this topic as it emphasizes the fact that nowadays the main asset of a company became its personal not its physical assets. PCMM is considered to be a roadmap for implementing human resource practices that continually improve the capability of an organization's human resources (Sigma, S 2009).

It was pointed out in several researches that a lot has changed in the field which forced the introduction of people aspect in the education process and that was inspired from the PCMM. It forced universities to expand their focus from just teaching the techniques to finding more proper ways for teaching the required set of soft skills that are needed for facing the real world (Bill Cuties et al. 2009).

Figure 1 illustrate the institutionalization actions that must be taken and followed for successful application of PCMM in any organization. 


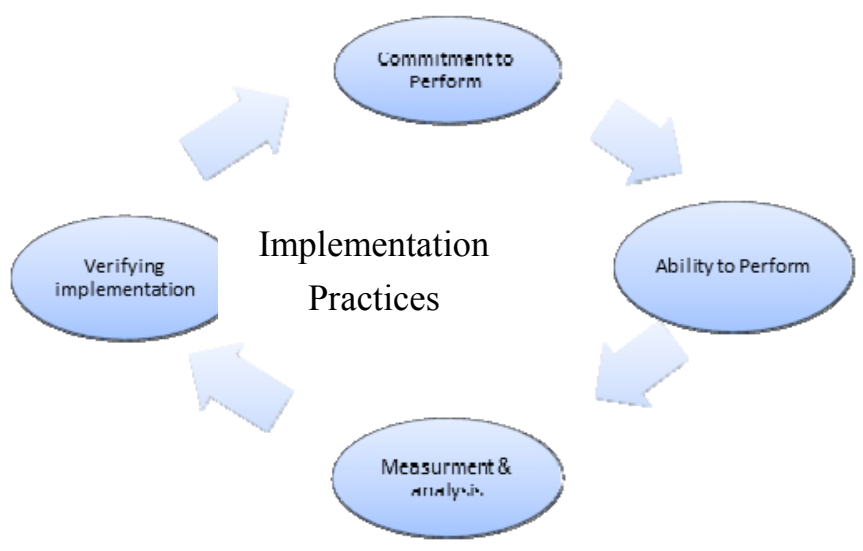

Figure 1. PCMM institutionalization actions

Institutionalization practices of the PCMM highlighted the fact that if the 4 actions illustrated in figure 1 are not applied the organization's performance will deteriorate gradually. (http://www.spaceminds.com/eng/peoplecmm.aspx).

\subsection{Approach to Research Literature Review}

IT was decided to follow the systematic literature review technique in this research to add more depth and quality to it. The use of this technique helps in providing evidence of the importance of the topic. Where generally Systematic literature review (SLR) gives an impression about other studies that are focusing on the same topic, highlighting its weaknesses and strengths. A SLR is carried throughout a series of steps including research question, research protocol, literature search, data extraction, quality appraisal data analysis and results, interpretation of results(Mary, C 2010). On an abstract level it includes identifying the concept of the study, studies used, results, and conclusions (check figure 2).

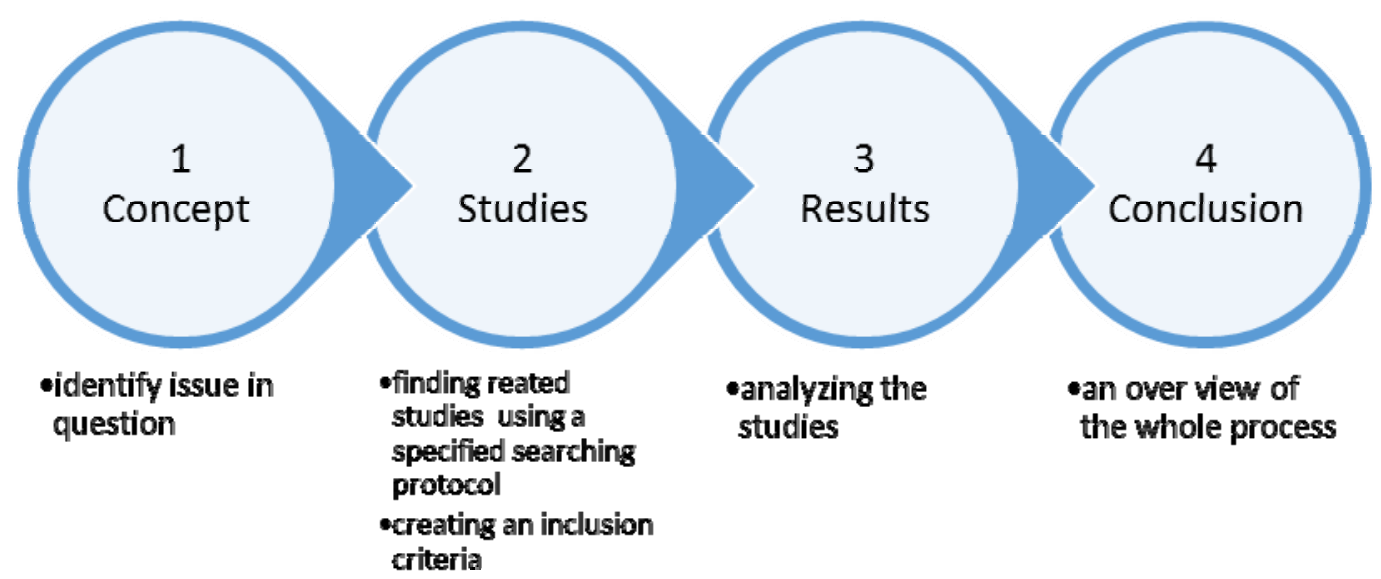

Figure 2. SLR abstract level

Step 1:

We had to identify our research question to create the concept of the research

- Importance of soft skills in software engineering

- The existence of a gap between the level of software engineering and computer science and the markets needs

- The role of higher education in creating or shrinking this gap

Step 2:

The web was used to search for studies using the identified questions. An inclusion and exclusion criteria in the 
selection of the studies that were reviewed was followed. Where the study had to be published in a well-established journal or conference (example IEEE, journal of systems and software, ACM and others). In addition to that all studies conducted before 2009 where excluded as old data might not be reliable in our study as everything in the field is subjected to rapid changes. Resulting in a list of 21 studies.

Step 3:

The 21 studies included were analyzed and the relevant data and techniques were extracted. This research focused on the aim, research question, method used, and results of these papers.

Step 4:

After performing step 3 the included studies and outcomes were identified and their impact on this study was stated. The SLR performed helped reaching the set of soft skills that was used in creating a survey which was distributed among graduating students in faculty of computer and information at Hellwan University. The data gathered from this survey was subjected to further analysis which helped in reaching a framework to help enhance the level of graduates and help solve the predicament of soft skills in software engineering field. In addition to that structured interviews were conducted with the managers in some Egyptian software development houses for backing up the topic in investigation.

\subsection{Literature Review}

This framework focuses on the gap between the level of computer and information graduate students and the real world industry in Egypt with respect to both technical skills and soft skills. This specific point has been covered in a lot of researches but nothing has been done to highlight this gap in Egypt and try to figure out whether it's the students fault or the teaching techniques used in Egyptian universities.

Three tables are used to summarize the applied SLR and displays the different studies conducted lately to cover this topic. Each table includes the papers and the journal or conference of publication, the purpose or aim of each study, the method used by the author, and the results. The papers were categorized according to the angle used to explore and handle problems of soft skills in our field whether the existence of gap in terms of soft skills shown in Table A1, applying new teaching approaches and techniques to minimize the gap shown in Table A2, and the gap presence from the markets point of view which is shown in Table A3.

The three tables are in appendix A, where table A1, the listed papers focused on the importance of soft skills and the existence of a gap between the actual level of soft skills of students and the level they are expected to have. All of the authors used either questionnaires or interviews in their surveys except for the paper "Understanding software development team performance" (G. P. SUDHAKAR. 2010), where the author only performed a SLR on the previous studies to prove the existence of a gap.

While the 8 studies mentioned in Table A2 showed the impact of the teaching techniques and approaches on the soft skills of computer science and software engineering students. The general conclusion was that even though students are aware of the influence of soft skills on their future careers they still haven't mastered them yet. Which is a result of the ignorance of universities of the topic and its importance. The authors also proved that universities should enhance their approaches in delivering the set of required soft skills to its students.

The 4 studies included in Table A3, exemplify how the market looks at the significance of soft skills for computer science and software engineering graduates. All the papers used the same approach to examine if the required soft skills are being met by their job applicants or not. This was achieved by analyzing job ads and relating certain soft skills to specific positions and the impact of those skills on the project's success.

\section{Method}

\subsection{Participant (Subject) Characteristics}

Throughout this study both questionnaires and interviews were conducted. The participants of the questionnaire where the fourth year students in the university. Team leaders and project managers participated in the interviews that were conducted in a couple of Egyptian software development houses

\subsection{Sampling Procedures}

The students participating in the questionnaire were in their $8^{\text {th }}$ and final semester. Students in their final semester should have been exposed to all the technical aspects and have a general idea of the field making them the optimum sample for conducting the required analysis.

This study is mainly focusing on the existing gap between the required technical and behavioral skills for the Egyptian software engineers so more investigation had to be made on where Egypt stands in this industry. 
Shockingly enough the ranking of some on the main universities in Egypt with regard to the level of education offered to software engineers was very bad. "Cairo University" came number 11 in Africa but number 1405 worldwide followed by "Ain shams University" being number 13 in Africa and number 1998 worldwide and then "Mansoura university" being number 14 in Africa and number 2102 worldwide. (http://www.topstudylinks.com/Top-Universities-in-Africa-tc1.aspx).

2.2.1 Sample Size, Power, and Precision of the Questionnaire

The questionnaire was distributed on all the 400 graduating students from computer and Information College in the year 2013, Hellwan University, resulting in 136 reliable and completed questionnaires. A formula was to calculate the confidence interval which turned out to be 6.48 using a confidence level of $95 \%$ http://www.surveysystem.com/sscalc.htm\#two). The students were required to state their GPA and department whether CS, IS, or SWE.

\subsubsection{Measures and Covariates}

The questionnaire was designed to cover both behavioral (non-technical) and functional (technical) skills. After analyzing the soft skills mentioned in the SLR, 29 soft skills were mentioned collectively in all the papers. Then the frequency by which these skills were mentioned was calculated and eliminated the ones with low mention frequency and grouped the skills that had different names but the same function. This resulted in a set of 17 skills that were used in the questionnaire shown in Table 1. The technical or functional skills where divided into project management, analysis and design, programing, testing and documentation and each of these five areas had a list of technical skills that students are required to know.

Table 1. Soft skill frequency

\begin{tabular}{lll}
\hline & \multicolumn{1}{c}{ Soft Skills mentioned in papers } & \# of times \\
\hline 1 & Communication(oral and written) & 17 \\
2 & Analytical and problem solving & 12 \\
3 & Team player & 12 \\
4 & Team work & 11 \\
5 & Management skills & 10 \\
6 & Interpersonal (presentation, listening, Negotiation skills) & 9 \\
7 & Innovative and Creative & 9 \\
8 & Self-learning & 8 \\
9 & Open and adaptive & 8 \\
10 & Leadership & 8 \\
11 & Organizational & 7 \\
12 & Planning & 7 \\
13 & Ability to work under independently & 6 \\
14 & fast learning & 5 \\
15 & Critical & 4 \\
16 & Work under pressure & 4 \\
17 & Decision making & 4 \\
18 & Design above functional level & 2 \\
19 & Shared beliefs and trust & 3 \\
20 & Emotional intelligence & 3 \\
21 & Commitment & 2 \\
22 & Research & 2 \\
23 & Concern with quality & 2 \\
24 & Cross-cultural skills (communication with different cultures ) & 2 \\
25 & Legal skills & 2 \\
26 & Awareness skills & 1 \\
27 & Language skills (written communication) & 1 \\
28 & Ethical, political, and economical skills \\
29 & Outsourced management skills & 1 \\
\hline & & 1 \\
\hline
\end{tabular}




\subsubsection{Research Design}

In order to make sure that the questionnaire was clear enough, it was distributed among some graduate students as well as professors and their feedback was taken into consideration. Where the size of the questionnaire had to be reduced into 2 pages and the used English had to be simplified. IT was assured that the students undergoing the survey were fully aware of the meaning of every question and skill. That is why the whole questionnaire was explained to them before they started answering.

The first part regarding the soft skills was designed where each of the 17 skills was evaluated from 3 different perspectives; the first one is "how important do you think this skill is?", the second is "How good do you think you are in this skill?", and the last one is "to which level has this skill been developed by the university?". The reason here for having 3 perspectives is to be able to evaluate the students, see if they understand the importance of these skills and the educational level they have been offered by the university. This was inspired from the SLR previously performed, where most the studies done only accounts for one or two aspect. Having these three aspects covered makes this research more robust.

\subsubsection{Experimental Manipulations or Interventions}

As for the questionnaire it was stated that for each question the 17 skill should be ranked on the scale from 1 to 5 with one being the lowest and 5 being the highest and the meaning of each question was fully explained. While the conducted interviews aimed to see how important do they think soft skills are and what are the most vital skills they are looking for in fresh graduates when they interview them. The questionnaire is provided in Apendix B.

\section{Results}

\subsection{Outcome of the Interviews}

One of the most important skills was Problem Solving and Analytical Thinking as they think that a software engineer should be able to think clearly and break down the problem to be able to create the system and apply the fixes required to complete the system. The second skill set was Communication Skills, including oral and written, and this skill is important as it has 2 perspectives, either communication with the customer or with other team members. Whereas employees are required to communicate with clients through meetings to understand exactly what is required from them and communicate with their team members to be able to deliver the required system in time, complete, correct and apply fixes within the development phase and follow up after implementation. Another very important skill from the employers' perspective is self-learning as any Software engineer would be required to complete a task in the project that they have never heard about before and need to get familiar with to be able to work on. Employees could also be required to use a new tool to complete a required task and this process must not take a lot of time to be completed. It has been acknowledged by managers that most of the fresh graduates lack communication skills and they also suffer from low experience level in how to act within the working environment (Rénette J. Blignaut et.al 2013).

\subsection{Statistics and Data Analysis}

Taking a more reflective look into the data and making sure that the data used in the analysis is reliable enough. The Z-score for all the soft skills with regard to each of the 3 question was calculated. The Z-score is basically calculated by subtracting the mean of our value from its raw score and dividing the result with the standard deviation of the used population (https://statistics.laerd.com/statistical-guides/standard-score.php). The Z-score analysis is used to help in assessing how far the data is from the normal or how much off target it is. Table 2 represent the $\mathrm{z}$ scores calculated for each skill with regard to all the questions. Where table 7 focuses on the maximum and minimum z-score of the skills examined which turned out to be the same for all the questions. Oral communication was the skill with the highest z-score with values $0.39,0.29,0.24$ for Q1, Q2, and Q3 and negotiation skill had the lowest score with values $0.004,0.007,0.012$ for Q1, Q2, and Q3. These values were checked in the $\mathrm{Z}$ score table and they were all on the positive side of the normal distribution curve, meaning that it is more than $50 \%$ of the population. The final step was to see the percentage of the students who gave these highest and lowest scores. As for the Oral communication, 65.17\%, 61.4\%, and $59.48 \%$ of the students gave it the highest score for Q1, Q2, and Q3 respectively. While only $50 \%$ of the students think negotiation skills is important with regard to Q1 and Q2 and $54 \%$ with regards to Q3 check table 3. 
Table 2. Z-Score for all soft skills and questions in the questionnaire

\begin{tabular}{llll}
\hline \multicolumn{1}{c}{ Skills } & \multicolumn{1}{c}{ Q1 } & \multicolumn{1}{c}{ Q2 } & \multicolumn{1}{c}{ Q3 } \\
\hline Oral communication & 0.38865 & 0.29606 & 0.23719 \\
Written communication & 0.28096 & 0.05892 & 0.15644 \\
learning & 0.03173 & 0.05913 & 0.04626 \\
negotiation skills & 0.00426 & 0.0007 & 0.01188 \\
Planning & 0.02307 & 0.01737 & 0.03257 \\
Time management & 0.35032 & 0.1853 & 0.17316 \\
Leadership skills & 0.26516 & 0.09973 & 0.1169 \\
Teamwork skills & 0.22435 & 0.07131 & 0.13824 \\
Decision Making & 0.37664 & 0.0484 & 0.11756 \\
Creativity & 0.25771 & 0.07703 & 0.06834 \\
Ethical Commitment & 0.10705 & 0.13901 & 0.22885 \\
Concern with overall quality & 0.07184 & 0.01606 & 0.02633 \\
problem solving & 0.04367 & 0.03426 & 0.08468 \\
presentation skills & 0.18753 & 0.148 & 0.11521 \\
Research skills & 0.19196 & 0.05292 & 0.05306 \\
ability to think under pressure & 0.03735 & 0.0102 & 0.02156 \\
Organization skills & 0.28396 & 0.0759 & 0.14411 \\
\hline
\end{tabular}

Table 3. The maximum and minimum Z-score skills for each question

\begin{tabular}{lll}
\hline & $\begin{array}{l}\text { Oral } \\
\text { communication }\end{array}$ & Negotiation \\
\hline Q1 & 0.1517 & 0 \\
Q2 & 0.1141 & 0 \\
Q3 & 0.0948 & 0.04 \\
\hline
\end{tabular}

\subsection{Ancillary Analyses}

Since this study's main focus is the importance of soft skills for SWE and CS graduates, only an analysis of this part of the survey is provided. The mean averages of the soft skills of all the departments for each question were analyzed, shown in table 4. Generally the mean average for each skill is calculated for each department separately. Where all the score given by the students for a specific skill are summed and divided by the number of students in this department. The average mean score is $(1+2+3+4+5) / 5=3$. For the CS, IS, and SWE departments Q1 and Q2 had high mean average but on the contrary Q3 had scores lower than the mean average. This was clarified when the mean averages of all the skills collectively were calculated with respect to each department and question. This indicates that the students find that their higher education providers don't support or provide enough attention to the soft skills and that they are aware of its importance, yet they are not provided with the facilities or enough attention to develop these skills, check Figure 3.

Table 4. Mean average of each skill for Q1, Q2, and Q3 for all the students

\begin{tabular}{lccccccccc}
\hline \multirow{2}{*}{ List of skills } & \multicolumn{4}{c}{ Q1 } & \multicolumn{3}{c}{} & \multicolumn{3}{c}{ Q2 } & \multicolumn{3}{c}{ Q3 } \\
\cline { 2 - 10 } & CS & IS & SWE & CS & IS & SWE & CS & IS & SWE \\
\hline Oral communication & 3.958 & 3.458 & 3.875 & 3.208 & 3.034 & 3.563 & 2.313 & 2.339 & 2.563 \\
Written communication & 3.542 & 3.508 & 3.750 & 3.167 & 3.254 & 3.688 & 2.479 & 2.831 & 2.813 \\
learning & 4.417 & 3.966 & 4.313 & 3.500 & 3.000 & 4.125 & 3.125 & 2.797 & 3.188 \\
negotiation skills & 3.583 & 3.119 & 4.125 & 2.792 & 2.780 & 3.875 & 2.167 & 2.407 & 2.813 \\
Planning & 4.250 & 3.729 & 4.250 & 3.438 & 2.966 & 3.688 & 2.521 & 2.458 & 2.563 \\
Time management & 4.354 & 4.254 & 4.250 & 3.146 & 3.220 & 3.188 & 2.396 & 2.593 & 2.438 \\
Leadership skills & 3.792 & 3.864 & 4.188 & 3.354 & 3.186 & 3.375 & 2.500 & 2.559 & 3.000 \\
Teamwork skills & 4.396 & 4.153 & 4.500 & 3.875 & 3.644 & 3.938 & 3.167 & 3.186 & 3.375 \\
Decision Making & 4.167 & 3.898 & 3.875 & 3.417 & 3.356 & 3.563 & 2.604 & 2.712 & 2.875 \\
Creativity & 4.250 & 3.847 & 4.250 & 3.375 & 3.051 & 3.750 & 2.229 & 2.305 & 2.625 \\
\hline
\end{tabular}




\begin{tabular}{llllllllll}
\hline Ethical Commitment & 4.146 & 3.576 & 4.000 & 3.917 & 3.271 & 3.750 & 2.833 & 2.661 & 3.188 \\
Concern with overall quality & 3.792 & 3.966 & 3.625 & 3.229 & 3.068 & 3.500 & 2.438 & 2.458 & 2.438 \\
problem solving & 4.104 & 3.627 & 4.563 & 3.417 & 3.288 & 3.938 & 2.729 & 2.407 & 3.063 \\
presentation skills & 3.729 & 3.797 & 4.063 & 3.458 & 3.186 & 3.438 & 2.667 & 2.695 & 3.063 \\
Research skills & 4.042 & 3.508 & 4.188 & 3.271 & 3.068 & 3.875 & 2.979 & 2.847 & 3.063 \\
ability to think under pressure & 4.021 & 3.627 & 4.250 & 3.604 & 3.085 & 3.813 & 3.188 & 2.661 & 3.313 \\
Organization skills & 3.667 & 3.729 & 3.750 & 3.167 & 3.169 & 3.188 & 2.500 & 2.441 & 3.313 \\
\hline
\end{tabular}

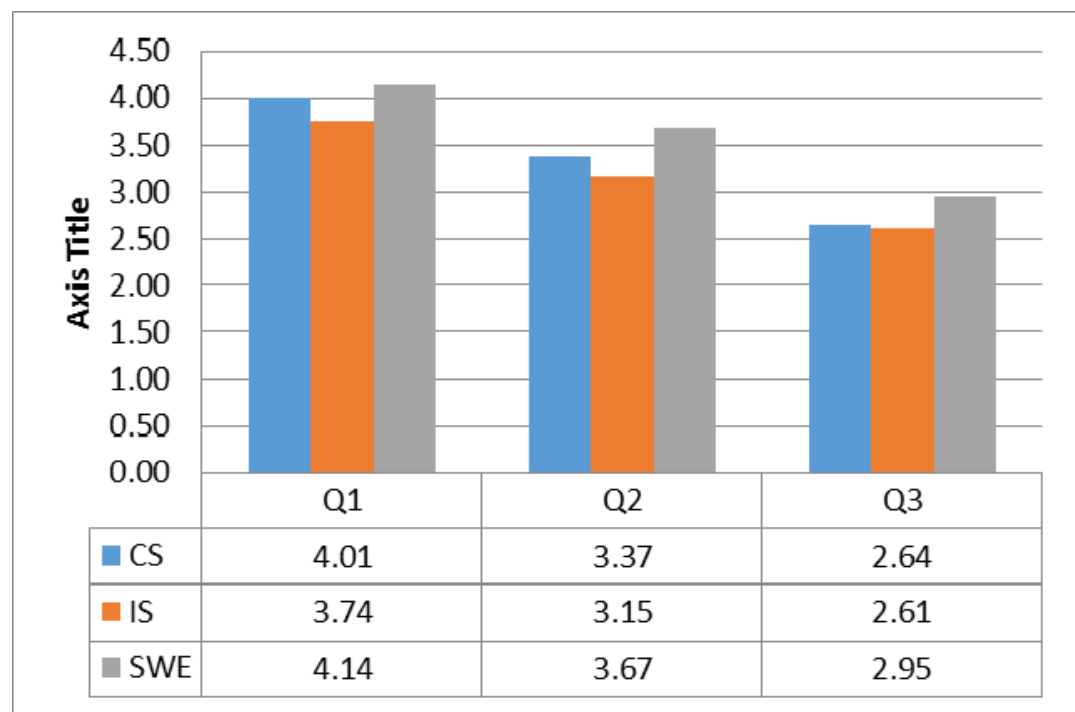

Figure 3. Mean average for soft skills of each department with regard to Q1, Q2, and Q3

Another point that came to is that the students from the Information System (IS) department gave the least averages in all the questions compared to the other 2 departments Computer Science (CS), and Software engineering (SWE), check Figure 3. Generally the students of all departments showed a great understanding of the importance of the soft skills and this awareness reflects on the averages of the second question. After the mean averages of all the soft skills were calculated, a reflective look was taken into each skill separately regarding each of the questions. Displaying the minimum and maximum mean average for each skill with regards to each of the three questions for the three departments CS, IS, and SWE Results are displayed in Tables 5 and 6.

Table 5. Maximum skill for each department with regards to Q1, Q2, and Q3

\begin{tabular}{cccc}
\hline & Q1 & Q2 & Q3 \\
\hline CS & Learning & Ethical Commitment & Ability to think under pressure \\
IS & Time management & Teamwork skills & Teamwork skills \\
SWE & Problem solving & Self-Learning & Teamwork skills \\
\hline
\end{tabular}

Table 6. Maximum skill for each department with regards to Q1, Q2, and Q3

\begin{tabular}{cccc}
\hline & Q1 & Q2 & Q3 \\
\hline CS & Written com & negotiation skills & negotiation skills \\
IS & negotiation skills & negotiation skills & creativity \\
& Concern with quality & $\begin{array}{c}\text { Organization skills/time } \\
\text { management }\end{array}$ & $\begin{array}{c}\text { concern with quality/ } \\
\text { time management }\end{array}$ \\
\hline
\end{tabular}


Even though the results generally reflect a great understanding from the students with regards to the importance of the behavioral skills, it is noticeable that there is a slight difference between the skills ranking and the observations from the interviews that were conducted with the Egyptian software houses managers along with the skill frequency table concluded from our SLR, check table 1. For instance, communication skills was ranked as one of the top skills that they look for when hiring and had the highest mention frequency, while the students ranking was lower than expected whether for the oral or written communication, results are displayed in the Figures 4 and 5. Nevertheless, the rest of the soft skills had a high mean average concerning the 3 questions.

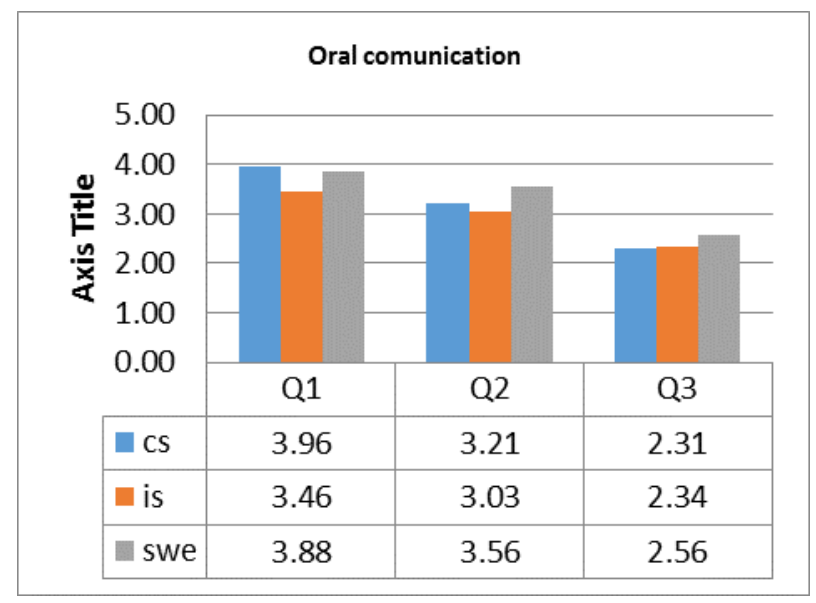

Figure 4. Oral communication

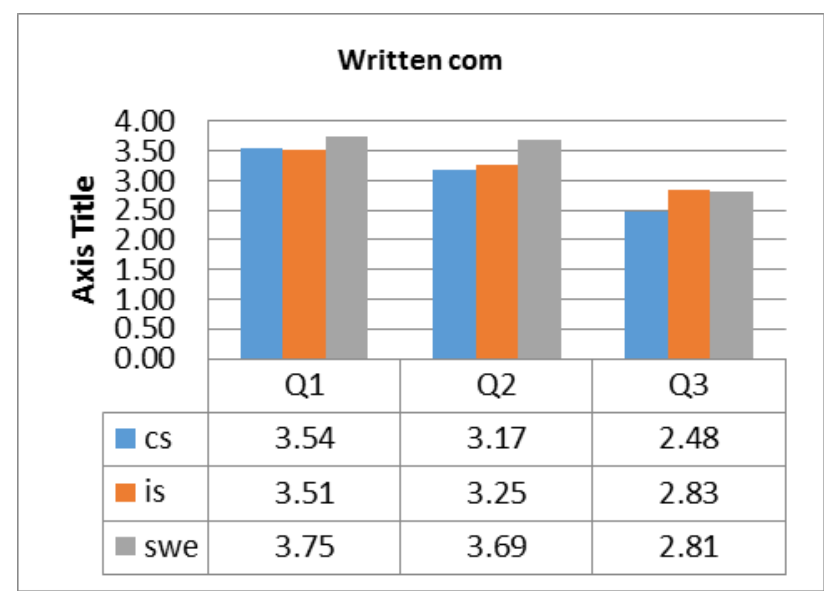

Figure 5. Written communication

\subsection{Participant Flow}

Only one of the authors participated in the process of questionnaire distribution and data gathering. Where all the 400 graduating students were asked to fill it. Only 223 students had the time and the will to participate resulting in 136 complete questionnaires. The remaining 87 questionnaires were not completed and the participants failed to provide some critical answers so they had to be excluded in the data analysis.

\subsection{Intervention or Manipulation Fidelity}

The interviews conducted took place over the phone with project managers in the Egyptian company "Emerge Technology" and "Connect me TV".

\section{Discussion}

In General, it is obvious that the importance of the behavioral skills is well perceived by graduating students. Not all of the results were high but most were higher than the mean average which is $(1+2+3+4+5) / 5=3$. AS a starter mean average for CS, IS and SWE with regards to Q1 is 3.96 reflecting the great understanding of student when it comes to the importance of these soft skills. Q2 the mean average of the 3 departments is 3.39 which is higher than 3 again indicating the students eagerness to develop these skills. As for the last question Q3 the mean average of the departments collectively is 2.73 which is lower than expected, indicating that the higher education process doesn't provide the students with the required skills. These results mostly prove the existence of a gap between the soft skills level for computer science graduates and the soft skills level which is required by the working field. In addition to highlighting the fact that students know the importance of soft skills for their future careers, try to acquire them, yet the higher education should emphasize more on enhancing these skills. In the future we intend to make this an online questionnaire which will make it easier to analyze and the data will be more updated as it can be done more frequently to check if the gap still exists.

\section{References}

Ahmed, F., \& Arab, U. (2012). Evaluating the Demand for Soft Skills in Software Development, (February).

Ahmed, F., Campbell, P., Beg, A., \& Capretz, L. F. (2011). What Soft Skills Software Architect Should Have? A Reflection from Software Industry, 5, 565-569.

Bender, L. L., Walia, G. S., Fagerholm, F., Pagels, M., Nygard, K. E., \& Münch, J. (2013). Measurement of the Non-Technical Skills of Software Professionals : An Empirical Investigation, 6, 478-483. 
Bill, C., Bill, H., \& Sall, M. (2009). People Capability Maturity Model (PCMM). $\mathrm{http}: / /$ www.spaceminds.com/eng/peoplecmm.asp

Bill, C., Bill, H., \& Sall. M. (2009). People Capability Maturity Model (P-CMM). Carnegie Mellon University, 2.0, 1-619.

Brechner, E. (2003). Things they would not teach me of in college: what microsoft developers learn later. In Companion of the 18th annual ACM SIGPLAN conference on Object-oriented programming, systems, languages, and applications, OOPSLA '03, pages 134\{136, New York, NY, USA, 2003. ACM.

Burlea, A. S. (2009). Success Factors for an Information Systems Projects Team, 9, $202-207$.

Carver, J., \& Kraft, N. (2011). Evaluating the testing ability of senior-level computer science students. In Software Engineering Education and Training (CSEE T), 2011 24th IEEE-CS Conference on, pages 169-178.

Cihan, P., \& Kalıpsiz, O. (2014). Evaluation of Students 'Skills in Software Project, 3(1).

Feldt, R., Höst, M., \& Lüders, F. (2009). Generic Skills in Software Engineering Master Thesis Projects: Towards Rubric-Based Evaluation. 2009 22nd Conference on Software Engineering Education and Training, 12-15. http://dx.doi.org/ 10.1109/CSEET.2009.54

Hazzan, O., \& Har-Shai, G. (2013). Teaching computer science soft skills as soft concepts. Proceeding of the 44th ACM Technical Symposium on Computer Science Education - SIGCSE, 13, 59. http://dx.doi.org/ $10.1145 / 2445196.2445219$

Jouny, I., \& Hornfeck, W. (2010). Teaching Soft Skills to ECE Students. 2010 IEEE Transforming Engineering Education: Creating Interdisciplinary Skills for Complex Global Environments, 1-12. http://dx.doi.org/10.1109/TEE.2010.5508889

Karunasekera, S., \& Bedse, K. (2007). Preparing Software Engineering Graduates for an Industry Career. 20th Conference on Software Engineering Education \& Training (CSEET'07), 97-106. http://dx.doi.org/10.1109/CSEET.2007.39

King, C. J. (2012). Restructuring Engineering Education. Journal of Engineering Education, 101(1), 1-5. Retrieved from http://www.jee.org/2012/January/01

Koppi, T., Edwards, S. L., Sheard, J., Naghdy, F., \& Brookes, W. (2010). The case for ict work-integrated learning from graduates in the workplace. In Proceedings of the Twelfth Australasian Conference on Computing Education - Volume 103, ACE '10, 107-116, Darlinghurst, Australia, Australia, 2010. Australian Computer Society, Inc.

Lingard, R. W. (2010). Teaching and Assessing Teamwork Skills in Engineering and Computer Science.

Lumpur, K., \& Nair, C. S. (2011). Trends in the quality of the student experience : An international perspective based on studies in three universities.

Lutz, M. (2013). Undergraduate Software Engineering at RIT: Past, Present, and Future. IEEE, 0018-9162/, $88-90$.

Makasiranondh, W., Maj, S. P., \& Veal, D. (2011). Student Opinions on their Development of Non-technical Skills in IT Education. Modern Applied Science, 5(2), 3-10. http://dx.doi.org/ 10.5539/mas.v5n2p3

Mary, C., Steps, S. R., Search, L., Extraction, D., Appraisal, Q., Analysis, D., ... Conference, P. J. (2010). Guidelines for writing systematic reviews.

Matturro, G. (2013). Soft skills in software engineering: A study of its demand by software companies in Uruguay. 2013 6th International Workshop on Cooperative and Human Aspects of Software Engineering (CHASE), 133-136. http://dx.doi.org/10.1109/CHASE.2013.6614749

Moreno, A. M., Sanchez-Segura, M. I., Medina-Dominguez, F., \& Carvajal, L. (2012). Balancing software engineering education and industrial needs. Journal of Systems and Software, 85(7), 1607-1620. http://dx.doi.org/ 10.1016/j.jss.2012.01.060

Radermacher, A. (2013). Gaps Between Industry Expectations and the Abilities of Graduates. SIGCSE' ACM, (ACM 978-1-4503-1868-6/13/03), 525-530.

Rénette, J. B., Isabella M. V., \& Karen, R. (2013). A Bridge Over the Computer Science Graduate Skill Gap, X World Conference on Computers in Education. 
Richardson, I., Reid, L., Seidman, S. B., Pattinson, B., \& Delaney, Y. (2011). Educating software engineers of the future: Software quality research through problem-based learning. 2011 24th IEEE-CS Conference on Software Engineering Education and Training (CSEE\&T), 91-100. http://dx.doi.org/10.1109/CSEET.2011.5876161

Robert, F., Martin, H., \& Frank, L. (2012). Generic Skills in Software Engineering Master Thesis Projects: Towards Rubric-Based Evaluation 18 sep 2012.

Sawyer, S. (2004). Software Development Teams.

Shkoukani, M., \& Lail, R. A. B. U. (2012). The Importance of Restructuring Software Engineering Education Strategies in Order to Minimize the Gap Between Academic Supply and Industry Demand in Software Engineering Field, 11(September).

Sigma, S. (2009). PCMM: Human Development Technology and People Process for the Future.

Simmons, C. B. (2010). Gaps in the Computer Science Curriculum: An Exploratory Study of Industry Professionals, $3-7$.

Sudhakar, G. P. (2010). Understanding software development team performance. ICFAI School of Information Technology (ISIT), 505-513.

Thurner, V., \& Böttcher, A. (2012.). Expectations and Deficiencies in Soft Skills Evaluating student competencies in Software Engineering education.

Thurner, V., Axel, B., \& Andreas, K. (2014). Identifying Base Competencies as Prerequisites for Software Engineering Education, (April), 1069-1076.

Yadin, A. (2012). Enhancing Information Systems Students' Soft Skill - a Case Study. International Journal of Modern Education and Computer Science, 4(10), 17-25. http://dx.doi.org/10.5815/ijmecs.2012.10.03

\section{Web References}

http://www.topstudylinks.com/Top-Universities-in-Africa-tc1.aspx)

http://www.surveysystem.com/sscalc.htm\#two)

https://statistics.laerd.com/statistical-guides/standard-score.php

\section{Appendix A}

\section{Tables of the Systematic literature review}

Table A1. The existence of a gap in terms of soft skills

\begin{tabular}{|c|c|c|c|}
\hline Study & Purpose/ Aim & Method & Results \\
\hline $\begin{array}{l}\text { Tends in the quality } \\
\text { of the students } \\
\text { experience: an } \\
\text { international } \\
\text { perspective based on } \\
\text { studies in } 3 \\
\text { universities } \\
\text { (Lumpur, K., \& } \\
\text { Nair, C. S. 2011) }\end{array}$ & $\begin{array}{l}\text { A review for the } \\
\text { student's experience in } \\
\text { universities that have } \\
\text { been showing the } \\
\text { student's satisfaction } \\
\text { surveys over the years }\end{array}$ & $\begin{array}{l}\text { The undergraduate and } \\
\text { postgraduate students that had } \\
\text { this survey received it online or } \\
\text { in person. } \\
5 \text { factors where in focus } \\
\text { - Learning infrastructure } \\
\text { - Quality of teacher } \\
\text { - Course design } \\
\text { - Student Assessments } \\
\text { - Administrative Matters }\end{array}$ & $\begin{array}{l}\text { The conclusion from the } \\
\text { results of this study showed } \\
\text { that students are aware of } \\
\text { the necessity of ensuring } \\
\text { that the courses offered } \\
\text { should cover this aspect. } \\
\text { These results also } \\
\text { recommend that the } \\
\text { evaluation and } \\
\text { improvement of the soft } \\
\text { skills for these students are } \\
\text { based on teaching tactics, } \\
\text { course design and operative } \\
\text { monitoring of students. }\end{array}$ \\
\hline $\begin{array}{l}\text { Enhancing } \\
\text { Information systems } \\
\text { student's soft } \\
\text { skills-a case study. } \\
\text { (Yadin, A. (2012) }\end{array}$ & $\begin{array}{l}\text { The aim of this paper is } \\
\text { to highlight the fact } \\
\text { that soft skills is as } \\
\text { important as technical } \\
\text { skills for IS graduates. }\end{array}$ & $\begin{array}{l}\text { They are taught a set of } \\
\text { technical skills related to system } \\
\text { design and analysis and are } \\
\text { required to complete a project } \\
\text { using the knowledge they } \\
\text { acquired in a professional way. }\end{array}$ & $\begin{array}{l}\text { This study proved that } \\
\text { when students are aware of } \\
\text { the importance of these } \\
\text { skills the pay more } \\
\text { attention to it and their } \\
\text { improvement curve is }\end{array}$ \\
\hline
\end{tabular}


These projects were graded twice, once by the professors and once by another team as peer review. significantly increased. Yet, there is still an enormous gap between what the market is looking for regarding these non-technical skills and the level of the students

\begin{tabular}{|c|c|}
\hline $\begin{array}{l}\text { Success Factors for } \\
\text { an Information } \\
\text { systems project } \\
\text { team, creating new } \\
\text { context } \\
\text { (Burlea, A. S. 2009) }\end{array}$ & $\begin{array}{l}\text { Explore the elements } \\
\text { that effects the success } \\
\text { and consistency of an } \\
\text { IS project team. } \\
\text { Examines the } \\
\text { relationship between } \\
\text { how information } \\
\text { systems quality in } \\
\text { collaboration with the } \\
\text { IS project team } \\
\text { member's } \\
\text { characteristics } \\
\text { influences the } \\
\text { performance of a team. }\end{array}$ \\
\hline
\end{tabular}

A series of 11 questions covering team's effort and form of structured and unstructured interviews. The author had to first set the goals which is formulating the proper knowledge, establishing the team size dynamics where asked in the

- The results of this research points out that there is a direct relation between the Information systems and the knowledge sharing in IS project teams.

- Stronger team structure when the team members like each other and cooperate

- The role and type of information system used has a direct impact on the level commitment of team members.

\begin{tabular}{ll}
\hline Generic skills in & Help higher education \\
software engineering & students develop their \\
master thesis & generic skills and \\
project: Towards a & finding out which skills \\
Rubric based & are developed \\
evaluation & throughout their \\
(Feldt, R et, al 2009) & masters.
\end{tabular}

23 master's students from 3 different Swedish universities were involved in this survey. A questionnaire was initially designed by one of the authors and reviewed by another one. The soft skills included in this questionnaire were in the syllabus of one of the courses offered by the university. The student had to rank these skills according to 2 perspectives, first was its importance and second was whether it was improved or not. In addition to the skills, there was a list of questions about their previous education support to this topic.
Most of the skills were rated by the students as important but the ordering of importance was not as expected by professionals. This might be because students are not fully aware of the meaning of each skill

\begin{tabular}{|c|c|}
\hline $\begin{array}{l}\text { Student opinions on } \\
\text { their development of } \\
\text { non-technical skills } \\
\text { in IT education. } \\
\text { (Makasiranondh, } \\
\text { W., Mai, S. P., \& }\end{array}$ & $\begin{array}{l}\text { Point out the } \\
\text { importance of a team } \\
\text { based project unit for } \\
\text { teaching } \\
\text { undergraduates soft } \\
\text { skills }\end{array}$ \\
\hline
\end{tabular}

Veal, D. 2011).

\section{This study offers a} better explanation for software development team performance. ( G. P. SUDHAKAR.
- Team

- Essential characteristics of

\section{Two different project students} took the questionnaire. The questionnaire involved 5 questions designed to address issues regarding the teaching of soft skills

the following conclusions were conducted:

1. Delivery mode preference for the nontechnical skills

2. Preferences of how non-technical skills could be taught

This study Offers a literature review of the previous work done in this topic
The systematic way of measuring team performance helps in detecting the level of team performance 


\begin{tabular}{|c|c|c|c|}
\hline 2010) & $\begin{array}{ll} & \text { teams } \\
\text { - } & \text { Team development } \\
\text { stages }\end{array}$ & & \\
\hline $\begin{array}{l}\text { Preparing Software } \\
\text { Engineering } \\
\text { graduates for an } \\
\text { industry Career } \\
\text { (Karunasekera, S., } \\
\text { \& Bedse, K. 2007) }\end{array}$ & $\begin{array}{l}\text { This is to help provide } \\
\text { students with } \\
\text { knowledge of both } \\
\text { technical and } \\
\text { non-technical skills } \\
\text { that are essential for } \\
\text { the working } \\
\text { environment }\end{array}$ & $\begin{array}{l}\text { Formal and informal evaluation. } \\
\text { Students took questionnaires } \\
\text { and the end of each semester, } \\
\text { rating the quality of teaching on } \\
\text { scale from } 1 \text { to } 5 \text { where } 5 \text { is the } \\
\text { highest. }\end{array}$ & $\begin{array}{l}\text { The results reflected that } \\
\text { the main goal of the } \\
\text { framework of achieving } \\
\text { appropriate learning } \\
\text { outcomes. } \\
\text { High scores were given } \\
\text { which helped in specifying } \\
\text { clear objectives for the } \\
\text { students }\end{array}$ \\
\hline $\begin{array}{l}\text { Evaluating of } \\
\text { students skills in SW } \\
\text { projects (Cihan, P., } \\
\text { \& Kalıpsiz, O. } \\
\text { 2014) }\end{array}$ & 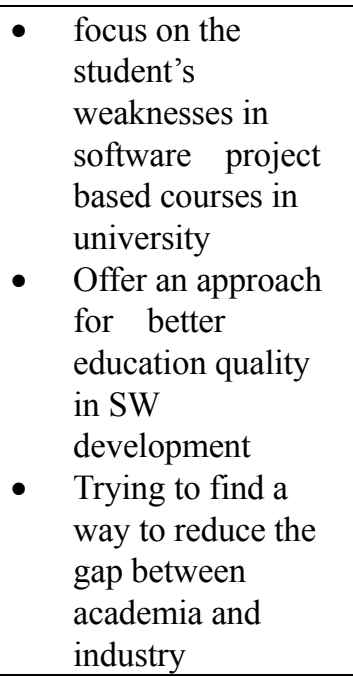 & $\begin{array}{l}\text { A questionnaire of } 20 \\
\text { questions covering the hard } \\
\text { and soft skills was } \\
\text { distributed in } 2 \text { different } \\
\text { universities } \\
189 \text { students participated in } \\
\text { the survey from } 3 \text { different } \\
\text { courses System analysis } \\
\text { and design, Software } \\
\text { engineering, \& Agile } \\
\text { software development }\end{array}$ & 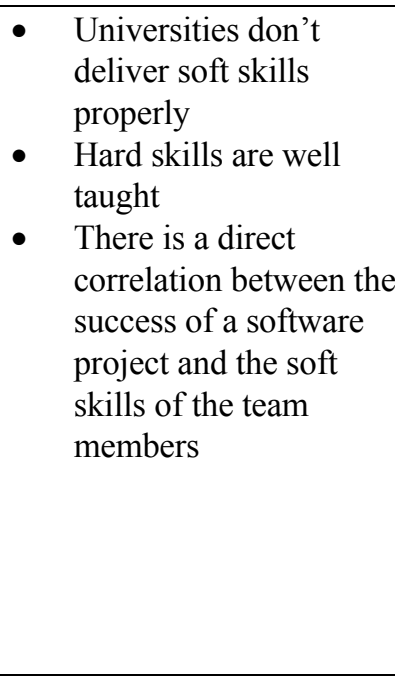 \\
\hline $\begin{array}{l}\text { Expectations \& } \\
\text { Deficiencies in soft } \\
\text { sills: Evaluating } \\
\text { Students } \\
\text { competencies } \\
\text { (Thurner, V., \& } \\
\text { Böttcher 2012) }\end{array}$ & $\begin{array}{l}\text { Clarify and develop the } \\
\text { student's level in their } \\
\text { academic study. Which } \\
\text { is due to the obstacles } \\
\text { in the learning process } \\
\text { resulting from the } \\
\text { improper delivery of } \\
\text { the basic competencies }\end{array}$ & $\begin{array}{l}\text { Questionnaire that aims to } \\
\text { capture the educator's } \\
\text { expectations on what student } \\
\text { should acquire in terms of soft s } \\
\text { (self, practical, cognitive and } \\
\text { social). } \\
\text {-Ask educators to state the level } \\
\text { of skills of their students against } \\
\text { what they expect } \\
\text {-Ask employers to state the level } \\
\text { of their job applicants against } \\
\text { what they expect } \\
\text {-Ask students what soft skill } \\
\text { they are required to know } \\
\text { against what they actually know }\end{array}$ & $\begin{array}{l}\text { The survey Confirmed the } \\
\text { importance of soft skills } \\
\text { and self-competencies as } \\
\text { the base for better and more } \\
\text { cultured skills in the higher } \\
\text { education } \\
\text { Confirmed the huge } \\
\text { existing gap between } \\
\text { expectations and reality for } \\
\text { students before, during, and } \\
\text { after } \\
\text { higher education and }\end{array}$ \\
\hline
\end{tabular}

Table A2. Applying new teaching approaches and techniques to minimize the gap

\begin{tabular}{llll}
\hline \multicolumn{1}{c}{ Study } & \multicolumn{1}{c}{ Purpose/ Aim } & \multicolumn{1}{c}{ Method } & \multicolumn{1}{c}{ Results } \\
\hline Under graduate Software & Developing a & Students had to take 2 & the students in this \\
Engineering at RIT: Past, & curriculum that bridges & basic courses and were & program are more suited \\
Present, and Future. (Lutz, & the gap between what & divided into 11 teams they & for the working \\
M. 2013) & computer science & were monitored from the & environment \\
& graduates know and & professors in active & learning environment. \\
& what's expected by the & These students used tools & \\
& workplace & &
\end{tabular}


that were developed and created by the industry for industrial use

\begin{tabular}{ll}
\hline $\begin{array}{l}\text { Teaching and assessing } \\
\text { teamwork skills in } \\
\text { engineering and computer }\end{array}$ & $\begin{array}{l}\text { Outlining an assessment } \\
\text { driven approach toward } \\
\text { teaching teamwork }\end{array}$ \\
science (Lingard, R. W. & skills for engineering \\
2010). & and computer science \\
students. Employers \\
often report that newly \\
hires typically do not \\
know how to \\
communicate and they \\
lack experience when it \\
comes to working in a \\
team
\end{tabular}

The author used 3 main

approaches

- Independent observation

- Evaluating individual contributions

- Peer reviews using a questionnaire that each team member had to fill

\author{
The importance of \\ teaching the soft skills is \\ widely understood but \\ finding effective \\ teaching tactics and \\ helpful methods of \\ assessing them is rather \\ challenging. \\ Teaching techniques \\ that were stated by the \\ author
}

- The group process and group roles

- Developing individual skills

- Oral team presentations

- Meeting report

- Reflective process Approaches to problem solving
The importance of restructuring the Software engineering education strategy in order to minimize the gap between academic supply and industry demand in software engineering field. (Shkoukani, M., \& Lail, R. A. B. U. 2012)
- Present overview of SWE education over years and the changes that happened

- Offers a clear vision of the gap between what is required by the industry and what's offered by the academia
The new techniques being used by the market were analyzed along with the academic curriculums being offered in the universities

$\begin{array}{ll}\begin{array}{l}\text { Identifying base } \\ \text { competencies as }\end{array} & \begin{array}{l}\text { Gain a more profound } \\ \text { look into the studying }\end{array} \\ \text { prerequisites for SWE } & \text { requirements for } \\ \text { education.( Thurner, V., } & \text { software engineering } \\ \text { Axel, B., \& Andreas, K. } & \text { and finding the } \\ \text { 2014) } & \text { difficulties that face } \\ & \text { students in this field }\end{array}$

Identifying base

prerequisites for SWE education.( Thurner, V., 2014)
- Collected a superset of all competencies out there and then filtered it to 100 base competencies that are related to SWE

- Define what the teachers expect from students regarding these skills

- Detect the skill level expected by the market

(1)
The lack of awareness of the new tactics used in the market by the universities effects the quality of education leading to low quality graduates
- Suggesting that continuous development should be applied by universities to reduce the gap

27 competencies out of the 100 were with the largest gap regarding what the market is expecting and what teachers found

- Resulting in the creation of 2 development tools to assess the students (self-assessment and knowledge testing tools)

\begin{tabular}{|c|c|c|c|}
\hline $\begin{array}{l}\text { Teaching computer science } \\
\text { oft skills as soft concept. } \\
\text { (Hazzan, O., \& Har-Shai, G. }\end{array}$ & $\begin{array}{l}\text { Implement and describe } \\
\text { a course which aims to } \\
\text { deliver soft skills for }\end{array}$ & $\begin{array}{l}\text { Design a course } \\
\text { covering an } \\
\text { introduction of soft }\end{array}$ & $\begin{array}{l}\text { Proves the } \\
\text { importance of } \\
\text { learning processes }\end{array}$ \\
\hline
\end{tabular}




\begin{tabular}{|c|c|c|c|}
\hline 2013) & $\begin{array}{l}\text { computer science. } \\
\text { Taking into } \\
\text { consideration that } \\
\text { these skills can't be } \\
\text { taught directly but rather } \\
\text { seized gradually over } \\
\text { time based on the } \\
\text { student acquiring them }\end{array}$ & $\begin{array}{l}\text { concept for computer } \\
\text { science studies. } \\
\text { The teaching } \\
\text { principles used were } \\
\text { active learning and } \\
\text { semi-structured } \\
\text { learning } \\
\text { - Soft skills teaching } \\
\text { principles covered } \\
\text { teamwork, reflection, } \\
\text { and diversity } \\
\text { Based on the } \\
\text { assignments, talks } \\
\text { and class } \\
\text { observations the } \\
\text { students } \\
\text { understanding of the } \\
\text { soft skills were } \\
\text { highlighted by } \\
\text { teachers } \\
\text { Students then had to } \\
\text { rank soft skills } \\
\text { according to its } \\
\text { importance } \\
\end{array}$ & $\begin{array}{l}\text { within software } \\
\text { development } \\
\text { processes in terms } \\
\text { of softs skills and } \\
\text { self-development. } \\
\text { - Students were able } \\
\text { to distinguish } \\
\text { between soft skills } \\
\text { and the skills } \\
\text { acquired during } \\
\text { their studies, } \\
\text { characterize these } \\
\text { skills, rank them, } \\
\text { and define the } \\
\text { concept of a soft } \\
\text { skill. } \\
\text { Listening skill was } \\
\text { the skill mentioned } \\
\text { the most with the } \\
\text { highest ranking } \\
\text { while patience was } \\
\text { the lowest ranked } \\
\text { skills }\end{array}$ \\
\hline $\begin{array}{l}\text { Educating Software } \\
\text { engineers of the Future: Soft } \\
\text { quality research through } \\
\text { Problem-Based learning. } \\
\text { (Richardson, I. 2011) }\end{array}$ & $\begin{array}{l}\text { Shows how problem } \\
\text { based learning (PBL) } \\
\text { approach can be used to } \\
\text { accomplish these goals } \\
\text { in a single course } \\
\text { module for SWE }\end{array}$ & $\begin{array}{l}\text { The PBL approach was } \\
\text { applied within a M.Cs } \\
\text { SWE quality module } \\
\text { and the outcomes were } \\
\text { evaluated expected results } \\
\text { of applying it in different } \\
\text { field. } \\
\text { Through the approach a } \\
\text { huge emphasis was put on } \\
\text { the requirement of soft } \\
\text { skills for SWE and } \\
\text { computer }\end{array}$ & $\begin{array}{l}\text { - For lecturers, it } \\
\text { delivered a different } \\
\text { tactic for teaching } \\
\text { that is more } \\
\text { interactive for } \\
\text { students and more } \\
\text { interesting } \\
\text { For students, it } \\
\text { helped them require } \\
\text { all the soft skills } \\
\text { that are important } \\
\text { for a successful } \\
\text { career in software } \\
\text { engineering. In } \\
\text { addition to } \\
\text { experience in real } \\
\text { world problem } \\
\text { solving }\end{array}$ \\
\hline $\begin{array}{l}\text { Teaching soft skills to ECE } \\
\text { students. (Jouny, I., \& } \\
\text { Hornfeck, W. 2010) }\end{array}$ & $\begin{array}{l}\text { Find a way to deliver } \\
\text { not- technical skills to } \\
\text { electrical and computer } \\
\text { engineering students as } \\
\text { they are hard to } \\
\text { describe, justify, teach } \\
\text { and evaluate. }\end{array}$ & $\begin{array}{l}\text { The following approach } \\
\text { was taken to teach the } \\
\text { specified soft skills } \\
\text { where the focus was on } \\
\text { making sure that students } \\
\text { can do the following } \\
\text { - Ability to } \\
\text { communicate } \\
\text { effectively through } \\
\text { 1st year seminar, } \\
\text { VAST seminar } \\
\text { introductory courses, } \\
\text { social science and } \\
\text { humanities course }\end{array}$ & $\begin{array}{l}\text { Achieve good results by } \\
\text { using an internal metrics } \\
\text { to measure the soft skills } \\
\text { of students during their } \\
\text { studying years and also } \\
\text { some additional years } \\
\text { after they graduate }\end{array}$ \\
\hline
\end{tabular}




\begin{tabular}{|c|c|c|c|}
\hline & & $\begin{array}{l}\text { work } \\
\text { understand the impact } \\
\text { of engineering } \\
\text { solutions in different } \\
\text { contexts using reports } \\
\text { \&seminars } \\
\text { - Understand the } \\
\text { necessity for and the } \\
\text { capability to } \\
\text { participate in the } \\
\text { self-learning process } \\
\text { after graduating } \\
\text { The familiarity of day } \\
\text { to day issues and how } \\
\text { to solve them using } \\
\text { critical thinking }\end{array}$ & \\
\hline $\begin{array}{l}\text { Gaps in the computer science } \\
\text { curriculum: An exploratory } \\
\text { study of industry } \\
\text { professionals (Simmons, C. } \\
\text { B. 2010) }\end{array}$ & $\begin{array}{l}\text { Investigate the } \\
\text { industry's need in terms } \\
\text { of soft skills for the } \\
\text { fresh graduates that they } \\
\text { hire }\end{array}$ & $\begin{array}{l}\text { Qualitative interviews } \\
\text { done with IT } \\
\text { professionals in fortune } \\
500 \text { business, small to } \\
\text { medium businesses and } \\
\text { non-profit organizations }\end{array}$ & $\begin{array}{l}\text { Results determined } \\
\text { that current curriculums } \\
\text { should focus more on } \\
\text { the personal skills along } \\
\text { with the technical skills }\end{array}$ \\
\hline
\end{tabular}

Table A3. The gap presence from the markets point of view

\begin{tabular}{|c|c|c|c|}
\hline Study & Purpose/ Aim & Method & Results \\
\hline $\begin{array}{l}\text { Evaluating the } \\
\text { demand for soft } \\
\text { skills in software } \\
\text { development. } \\
\text { (Ahmed, F., \& } \\
\text { Arab, U. 2012) }\end{array}$ & $\begin{array}{l}\text { Highlighting the } \\
\text { importance of soft skills } \\
\text { from the markets } \\
\text { perspective and help } \\
\text { define the soft skills that } \\
\text { are in high demand. }\end{array}$ & $\begin{array}{l}\text { Nine soft skills were the } \\
\text { main focus of this study. } \\
\text { Ads were included and } \\
\text { analyzed only if it had at } \\
\text { least one of these nine } \\
\text { skills. Each one of the nine } \\
\text { skills was listed among } \\
\text { each of the jobs. A } \\
\text { 3-point scale was used to } \\
\text { represent the results, } \\
\text { stating whether this skills } \\
\text { was in high demand, } \\
\text { moderate demand, or low } \\
\text { demand. }\end{array}$ & $\begin{array}{l}\text { The survey indicates } \\
\text { that soft skills are } \\
\text { demanded in the } \\
\text { software industry but } \\
\text { only to a limited } \\
\text { extent. Reflecting the } \\
\text { fact that employers } \\
\text { themselves are not } \\
\text { fully aware of its } \\
\text { importance and how } \\
\text { each profession should } \\
\text { be connected to the } \\
\text { correct soft skill. }\end{array}$ \\
\hline $\begin{array}{l}\text { Balancing software } \\
\text { engineering } \\
\text { education and } \\
\text { industrial needs } \\
\text { (Moreno, A. M. et, } \\
\text { al 2012) }\end{array}$ & $\begin{array}{l}\text { Analyze whether SE } \\
\text { education delivers the } \\
\text { knowledge that is required } \\
\text { by students in their } \\
\text { working life or not }\end{array}$ & $\begin{array}{l}\text { Comparisons between } \\
\text { SE2004 and GSwE2009in } \\
3 \text { different industry profiles } \\
\text { was conducted to highlight } \\
\text { the changes in the } \\
\text { understanding of the } \\
\text { required knowledge and } \\
\text { different career paths in } \\
\text { SWE }\end{array}$ & $\begin{array}{l}\text { None of the } 3 \text { industry } \\
\text { profiles is completely } \\
\text { covered by either } \\
\text { SE2004 or } \\
\text { GSwE2009. } \\
\text { The hugest gap was } \\
\text { related to IT business } \\
\text { consultancy } \\
\text { GSwE2009 is missing } \\
\text { some important soft } \\
\text { skills }\end{array}$ \\
\hline $\begin{array}{l}\text { Soft skills in } \\
\text { software } \\
\text { engineering: A } \\
\text { study of its demand } \\
\text { by software }\end{array}$ & $\begin{array}{l}\text { Aimed to answer } 2 \\
\text { questions: } \\
\text { - What are the soft } \\
\text { skills most in } \\
\text { demand by software }\end{array}$ & $\begin{array}{l}\text { Review a set of } 678 \\
\text { jobs advertisements } \\
\text { related to software } \\
\text { engineering in order to } \\
\text { identify what skills are }\end{array}$ & $\begin{array}{l}\text { Most important skills } \\
\text { for all SWE jobs } \\
\text { - } \quad \text { Team work } \\
\text { - } \quad \text { Communication } \\
\quad \text { skills initiative }\end{array}$ \\
\hline
\end{tabular}


companies in

Uruguay.

(Matturro, G.

(2013) companies in

Uruguay

- What are the soft skills most valued in terms of the main SWE processes
What soft skills software architects should have? A reflection from Software Industry. (Ahmed, F. et, al. 2011)
Offering a clear image about the soft skills that software architects are required to possess by the industry.

Highlighting the current status of the skills being used most in demand by

SW companies

- Top 5 soft skills in each job title was identified

- Results were compared with other studies in different countries and proactivity

- Analytical/proble m-solving skills

- Interpersonal skills

The results showed that the demand of these soft skills is as important as technical skills that SWE must have to get a job position and helps SW organizations achieve their goals

- Communication and management skills where in high demand for SW architects instead of the expected skills (creativity and technical ability )

- $\quad$ Ability to work independently, innovative\& open $\&$ and adaptable to changes where surprisingly low in demand

\section{Appendix B}

\section{Soft skills Questionnaire}

\begin{tabular}{|c|c|c|c|c|c|c|c|c|c|c|c|c|c|c|c|}
\hline \multirow[t]{2}{*}{ List of skills } & \multicolumn{5}{|c|}{$\begin{array}{c}\text { How important do you } \\
\text { think this skill is? }\end{array}$} & \multicolumn{5}{|c|}{$\begin{array}{c}\text { How good do you } \\
\text { think you are in this } \\
\text { skill } \\
\end{array}$} & \multicolumn{5}{|c|}{$\begin{array}{c}\text { To which level has this } \\
\text { skill been developed by } \\
\text { the college }\end{array}$} \\
\hline & 1 & 2 & 3 & 4 & 5 & 1 & 2 & 3 & 4 & 5 & 1 & 2 & 3 & 4 & 5 \\
\hline \multicolumn{16}{|l|}{ Oral communication } \\
\hline \multicolumn{16}{|l|}{ Written communication } \\
\hline \multicolumn{16}{|l|}{ Self-learning } \\
\hline \multicolumn{16}{|l|}{ negotiation skills } \\
\hline \multicolumn{16}{|l|}{ Planning } \\
\hline \multicolumn{16}{|l|}{ Time management } \\
\hline \multicolumn{16}{|l|}{ Leadership skills } \\
\hline \multicolumn{16}{|l|}{ Teamwork skills } \\
\hline \multicolumn{16}{|l|}{ Decision Making } \\
\hline \multicolumn{16}{|l|}{ Creativity } \\
\hline \multicolumn{16}{|l|}{ Ethical Commitment } \\
\hline \multicolumn{16}{|l|}{ Concern with overall quality } \\
\hline \multicolumn{16}{|l|}{ problem solving } \\
\hline \multicolumn{16}{|l|}{ presentation skills } \\
\hline \multicolumn{16}{|l|}{ Research skills } \\
\hline \multicolumn{16}{|l|}{ Ability to think under pressure } \\
\hline Organization skills & & & & & & & & & & & & & & & \\
\hline
\end{tabular}




\section{Copyrights}

Copyright for this article is retained by the author(s), with first publication rights granted to the journal.

This is an open-access article distributed under the terms and conditions of the Creative Commons Attribution license (http://creativecommons.org/licenses/by/3.0/). 